\title{
VARIATION OF SEED MORPHOLOGY OF TROLLIUS EUROPAEUS L. AND TROLLIUS ALTISSIMUS CRANTZ (RANUNCULACEAE)
}

\author{
WOJCIECH ANTKOWIAK ${ }^{1}$, IRMINA MACIEJEWSKA-RUTKOWSKA ${ }^{2}$, \\ ANDRZEJ M. JAGODZIŃSKI ${ }^{3,4}$, DARIUSZ KAYZER ${ }^{5}$, MAŁGORZATA KLIMKO ${ }^{1}$ \\ ${ }^{1}$ Department of Botany, University of Life Sciences in Poznań \\ Wojska Polskiego 71c, 60-625 Poznań, Poland \\ 2 University of Life Sciences in Poznań \\ Wojska Polskiego 71d, 60-625 Poznań, Poland \\ e-mail: irminamr@up.poznan.pl \\ ${ }^{3}$ Department of Forest Protection, University of Life Sciences in Poznań \\ Wojska Polskiego 71c, 60-625 Poznań, Poland \\ ${ }^{4}$ Institute of Dendrology, Polish Academy of Sciences \\ Parkowa 5, 62-035 Kórnik, Poland \\ ${ }^{5}$ Department of Agricultural Economics and Management, \\ University of Life Science in Poznań \\ Wojska Polskiego 28, 60-637 Poznań, Poland
}

(Received: June 7, 2009. Accepted: November 18, 2009)

\begin{abstract}
The aim of this study was to investigate seed morphology and intra- and inter-population variation of seeds of Trollius europaeus L. and Trollius altissimus Crantz., two controversial species regarding their taxonomical position. We analyzed seed-coat microsculpture and some biometrical traits (length and width, width/length ratio, volume and projected perimeter). Seed sculpture did not differ between species, but seeds of T. altissimus were usually larger than seeds of T. europaeus. Although species differed significantly in seed morphology, it was possible to show the populations of both species that were similar regarding the analyzed seed traits. We noted a significant inter-population differentiation of seeds in both species with respect to seed-coat microornamentation and biometrical traits. We conclude that $T$. europaeus and $T$. altissimus are probably not two distinct species, but $T$. europaeus should be divided into two lower taxa in the rank of variety or subspecies.
\end{abstract}

KEY WORDS: morphology, seeds, Trollius europaeus, T. altissimus, variation.

\section{INTRODUCTION}

Trollius L. (Ranunculaceae) (globeflower) consists of arctic-alpine perennial herbs, native to the cool, temperate regions of the northern hemisphere. The greatest diversity of Trollius species has been noted in Asia, especially within southern China (Després et al. 2003). They usually grow in moist meadows and in heavy and clay soils. Thirty globeflower species have been described, but the systematic position of some is still controversial due to the highly variable intrageneric morphological characters of Trollius. Additionally, some species are not strictly differentiated, their ranges at least partly overlap and there exist intermediate forms between them (Doroszewska 1974).

Among three European species of this genus, T. europaeus L. has the widest distributional range. It occupies extensive areas of northern and central lowland areas of Europe, having large and generally continuously distributed populations. Towards the south of the continent, its populations appear to be more scattered, growing only in the mountains. As with other Trollius species, it is also characterized by substantial morphological variation, especially in its foliage and generative organs, even within a given population (Doroszewska 1974). Similarly, high genetic variability of $T$. europaeus has been also documented (Després et al. 2002). As Doroszewska (1974) pointed out, all these factors have resulted in challenges in its intraspecific classification; numerous taxa have been described as forms, varieties, subspecies or even separate species. We believe that only two varieties of this species should be recognized, T. europaeus var. europaeus (grows within the whole range of species in Europe) and T. europaeus var. 
TABLE 1 . The origin of analyzed populations of Trollius species and the number of seeds, of which the morphology was investigated.

\begin{tabular}{|c|c|c|c|c|c|}
\hline $\begin{array}{c}\text { No } \\
\text { of population }\end{array}$ & Species & Origin in Poland & $\begin{array}{l}\text { Longitiude } \\
\text { and latitude }\end{array}$ & $\begin{array}{l}\text { Altitude } \\
\text { (m a.s.l) }\end{array}$ & $\begin{array}{c}\text { No } \\
\text { of measured seeds }\end{array}$ \\
\hline 1 & T. europaeus & Kujawsko-Pomorskie Province - Sitowiec & $\begin{array}{l}53^{\circ} 22^{\prime} \mathrm{N} \\
17^{\circ} 46^{\prime} \mathrm{E}\end{array}$ & 141 & 337 \\
\hline 2 & T. europaeus & Wielkopolska Province - Ferdynandowo & $\begin{array}{l}53^{\circ} 15^{\prime} \mathrm{N} \\
17^{\circ} 22^{\prime} \mathrm{E}\end{array}$ & 118 & 112 \\
\hline 3 & T. europaeus & Wielkopolska Province - Liszkowo & $\begin{array}{l}53^{\circ} 14^{\prime} \mathrm{N} \\
17^{\circ} 19^{\prime} \mathrm{E}\end{array}$ & 119 & 153 \\
\hline 4 & T. europaeus & Wielkopolska Province - Popówek & $\begin{array}{l}53^{\circ} 17^{\prime} \mathrm{N} \\
17^{\circ} 18^{\prime} \mathrm{E}\end{array}$ & 112 & 158 \\
\hline 5 & T. europaeus & Wielkopolska Province - Łobżenica & $\begin{array}{l}53^{\circ} 16^{\prime} \mathrm{N} \\
17^{\circ} 16^{\prime} \mathrm{E}\end{array}$ & 113 & 94 \\
\hline 6 & T. europaeus & Wielkopolska Province - Mnichy I & $\begin{array}{l}52^{\circ} 33^{\prime} \mathrm{N} \\
15^{\circ} 58^{\prime} \mathrm{E}\end{array}$ & 72 & 168 \\
\hline 7 & T. europaeus & Wielkopolska Province - Mnichy II & $\begin{array}{l}52^{\circ} 33^{\prime} \mathrm{N} \\
15^{\circ} 58^{\prime} \mathrm{E}\end{array}$ & 72 & 132 \\
\hline 8 & T. europaeus & Wielkopolska Province - Mnichy Młyn & $\begin{array}{l}52^{\circ} 32^{\prime} \mathrm{N} \\
15^{\circ} 59^{\prime} \mathrm{E}\end{array}$ & 71 & 804 \\
\hline 9 & T. europaeus & Wielkopolska Province - Uściskowo & $\begin{array}{l}52^{\circ} 37^{\prime} \mathrm{N} \\
16^{\circ} 45^{\prime} \mathrm{E}\end{array}$ & 75 & 153 \\
\hline 10 & T. europaeus & Wielkopolska Province - Dziewicza Góra & $\begin{array}{l}52^{\circ} 28^{\prime} \mathrm{N} \\
17^{\circ} 01^{\prime} \mathrm{E}\end{array}$ & 76 & 163 \\
\hline 12 & T. europaeus & Wielkopolska Province - Trzcielińskie Bagno II & $\begin{array}{l}52^{\circ} 18^{\prime} \mathrm{N} \\
16^{\circ} 42^{\prime} \mathrm{E}\end{array}$ & 71 & 145 \\
\hline 13 & T. altissimus & Małopolska Province - Tatra Mts - Bobrowiec & $\begin{array}{l}49^{\circ} 15^{\prime} \mathrm{N} \\
19^{\circ} 47^{\prime} \mathrm{E}\end{array}$ & 2246 & 144 \\
\hline 14 & T. altissimus & Podkarpackie Province - Bieszczady Mts - Połonina Wetlińska & $\begin{array}{l}49^{\circ} 09^{\prime} \mathrm{N} \\
22^{\circ} 33^{\prime} \mathrm{E}\end{array}$ & 1255 & 108 \\
\hline 15 & T. altissimus & Podkarpackie Province - Bieszczady Mts - Połonina Bukowska & $\begin{array}{l}49^{\circ} 03^{\prime} \mathrm{N} \\
22^{\circ} 46^{\prime} \mathrm{E}\end{array}$ & 1253 & 185 \\
\hline 16 & T. altissimus & Dolnośląskie Province - Bystrzyckie Mts - Zieleniec & $\begin{array}{l}50^{\circ} 21^{\prime} \mathrm{N} \\
16^{\circ} 25^{\prime} \mathrm{E}\end{array}$ & 760 & 464 \\
\hline 17 & T. altissimus & Dolnośląskie Province - Stolowe Mts - Rogowa Kopa & $\begin{array}{l}50^{\circ} 28^{\prime} \mathrm{N} \\
16^{\circ} 20^{\prime} \mathrm{E}\end{array}$ & 770 & 384 \\
\hline
\end{tabular}

transsilvanicus (Schur) Bł. (occurs in Central Europe). Tutin (1993) and Pankhurst (2006) identified two subspecies of European globeflower: T. europaeus subsp. europaeus, which corresponds to Doroszewska's var. europaeus, and T. europaeus subsp. transsilvanicus (Schur) Domin, which is basically equivalent of Doroszewska's var. transsilvanicus and naturally occurs from the Southern Alps to the Carpathians. Chrtek and Chrtkova (1979) recognized the above-mentioned subspecies as a separate species, T. europaeus and Trollius altissimus Crantz. This view is shared by other botanists in Central and Eastern Europe (Mosyakin and Fedoronchuk 1999; Mirek et al. 2002; Piękoś-Mirkowa and Mirek 2003; Zicha 2009). Both taxa have diffe- rent geographical habitats, particularly in mountain ranges. Trollius europaeus s.s. appears only in lowlands and in the lower mountain levels whereas $T$. altissimus is a plant of the mountain regions, above forest zone. Morphological distinction between both species is based on the shape and size of the stigma and the size of follicle beaks.

The seeds of the Trollius genus, as with most of Ranunculaceae, develop from anatropous, bitegmic and crassinucellate ovules (Corner 1976; Brückner 1994; Endress and Igersheim 1999). The inner structure is also typical of Ranunculaceae. While in dormancy, the seeds consist of small, rudimentary embryos, surrounded by a living endosperm containing lipids and protein bodies. The testa is de- 
eply pigmented, multi-layered and incomplete at the micropylar end of the seed (Hepher and Roberts 1985a, b). The seeds are small, not more than $2 \mathrm{~mm}$ long, but relatively heavy, without any apparent adaptations for vector dispersal (Hitchmough 2003). A portion of the seeds are generally eaten by larvae of Chiastocheta Pokorny species, of which the imago pollinate Trollius flowers (e.g. Yu and Ridley 2003; Després et al. 2007 and others).

The details of seed morphology of species within the Trollius genus have not been documented. In recent years, however, seed traits, especially seed-coat micromorphology, have proven to be a useful taxonomic criterion within many different taxonomic groups at species level, including the species of Ranunculaceae (e.g. Cappelletti and Poldini 1984; Feng-Xia 2003).

The goal of this study was to investigate seed morphology of $T$. europaeus and $T$. altissimus, especially seed-coat microsculpture, as well as intra- and inter-population variation of both species. Additionally, we wanted to investigate the utility of seed morphology in differentiating the two species.

\section{METHODS}

We collected samples of ripe seeds of T. europaeus of 12 populations and T. altissimus of five populations from natural localities in Poland in the years 1999-2001 (Table 1). Every gathered sample consisted of seeds originated from at least 30 specimens. The samples were kept separate at room temperature and were analyzed at the same time. They were not dissected, but only cleaned. The using of a scanning electron microscope (LEO 435 VP, Leo Electron Microscopy Ltd., Cambridge, U.K.) enabled us to investigate seed ultrastructure of both species. The terminology of Barthlott (1981), which is based on SEM observations of epidermal and seed coat surface of 5000 vascular species, is used in our study.

The biometrical traits of seeds of both species were analyzed using the computer programme WinSeedle ${ }^{\mathrm{TM}}$ 2003a (Régent Instruments Inc., Quebec, Canada). The number of seeds investigated varied among locations due to their availability. We analyzed ca. 2600 seeds of T. europaeus and ca. 1300 seeds of T. altissimus. We analyzed se- ed morphology variation both at the species and population level. The following seed traits were measured: length $(\mathrm{mm})$, width $(\mathrm{mm})$, width/length ratio, volume $\left(\mathrm{mm}^{3}\right)$ and projected perimeter $(\mathrm{mm})$. The arithmetical mean, standard deviation and coefficient of variation for each mentioned trait were calculated at the population level. In addition, multivariate analysis of variance in one-way classification was used (Morrison 1976). Our null hypothesis was that there were no differences among the mean values of the traits of investigated populations with regard to the mean values of biometrical traits. It was rejected at the á $=0.05$ level of significance.

Mean values of traits of particular populations were compared with the overall mean values of all populations. Using $T_{0, i \bullet}^{2}$ and $T_{0, \bullet j}^{2}$ statistics, populations and traits were determined to be responsible for rejection of general hypothesis (Lejeune and Caliński 2000). Our analysis allowed us to position the Trollius populations in canonical coordinates.

Multivariate differences among the means of the studied seed traits were investigated to estimate similarities of the populations within species. The Mahalanobis distance was assumed as a measure of those differences; it was tested using the Laweley-Hotelling statistic. In addition, the significance of contrast between $T$. europaeus and T. altissimus was investigated (Lejeune and Caliński 2000).

\section{RESULTS}

The seeds of T.europaeus and T. altissimus are superficially very similar. Seeds of both species are elliptical or ovate. The transversal sections of seeds of each species are triangular. Seeds of both species are also slightly narrower toward the micropylar apex. The micropylum of both species is situated in the middle, on the edge of the apex. The apex and the base are also obtusely curved.

Closer examination of the seed-coat of both species showed considerable variation in its texture even at the population level. It did not reveal any important distinctions between $T$. europaeus and $T$ altissimus. The testa cells were pentagonal or hexagonal, rarely tetragonal, more or less isodiametric or slightly elongate parallel to the seed axis. Their anticlinal walls were straight to rounded, thickened

TABLE 2. Comparison of mean values of the analyzed seed features ( \pm SE) of Trollius europaeus and T. altissimus. ANOVAs were performed to show the differences among both species.

\begin{tabular}{|c|c|c|c|c|}
\hline Seed feature & $\begin{array}{c}\text { Mean value } \\
\text { for } T . \text { europaeus }\end{array}$ & $\begin{array}{c}\text { Mean value } \\
\text { for } T \text {. altissimus }\end{array}$ & $\begin{array}{l}\text { ANOVA } \\
\mathrm{P}>\mathrm{F}\end{array}$ & $\begin{array}{c}\text { Tendency } \\
(+/-\%)\end{array}$ \\
\hline Length $[\mathrm{mm}]$ & $\begin{array}{c}1.615 \\
(0.003)\end{array}$ & $\begin{array}{c}1.660 \\
(0.006)\end{array}$ & $<0.0001$ & +2.8 \\
\hline Width [mm] & $\begin{array}{c}1.099 \\
(0.004)\end{array}$ & $\begin{array}{c}1.167 \\
(0.006)\end{array}$ & $<0.0001$ & +6.2 \\
\hline $\mathrm{W} / \mathrm{L}$ ratio & $\begin{array}{c}0.682 \\
(0.002)\end{array}$ & $\begin{array}{c}0.705 \\
(0.003)\end{array}$ & $<0.0001$ & +3.4 \\
\hline Volume $\left[\mathrm{mm}^{3}\right]$ & $\begin{array}{c}0.279 \\
(0.003)\end{array}$ & $\begin{array}{c}0.338 \\
(0.004)\end{array}$ & $<0.0001$ & +21.1 \\
\hline Perimeter [mm] & $\begin{array}{c}4.466 \\
(0.011)\end{array}$ & $\begin{array}{c}4.926 \\
(0.024)\end{array}$ & $<0.0001$ & +10.3 \\
\hline
\end{tabular}



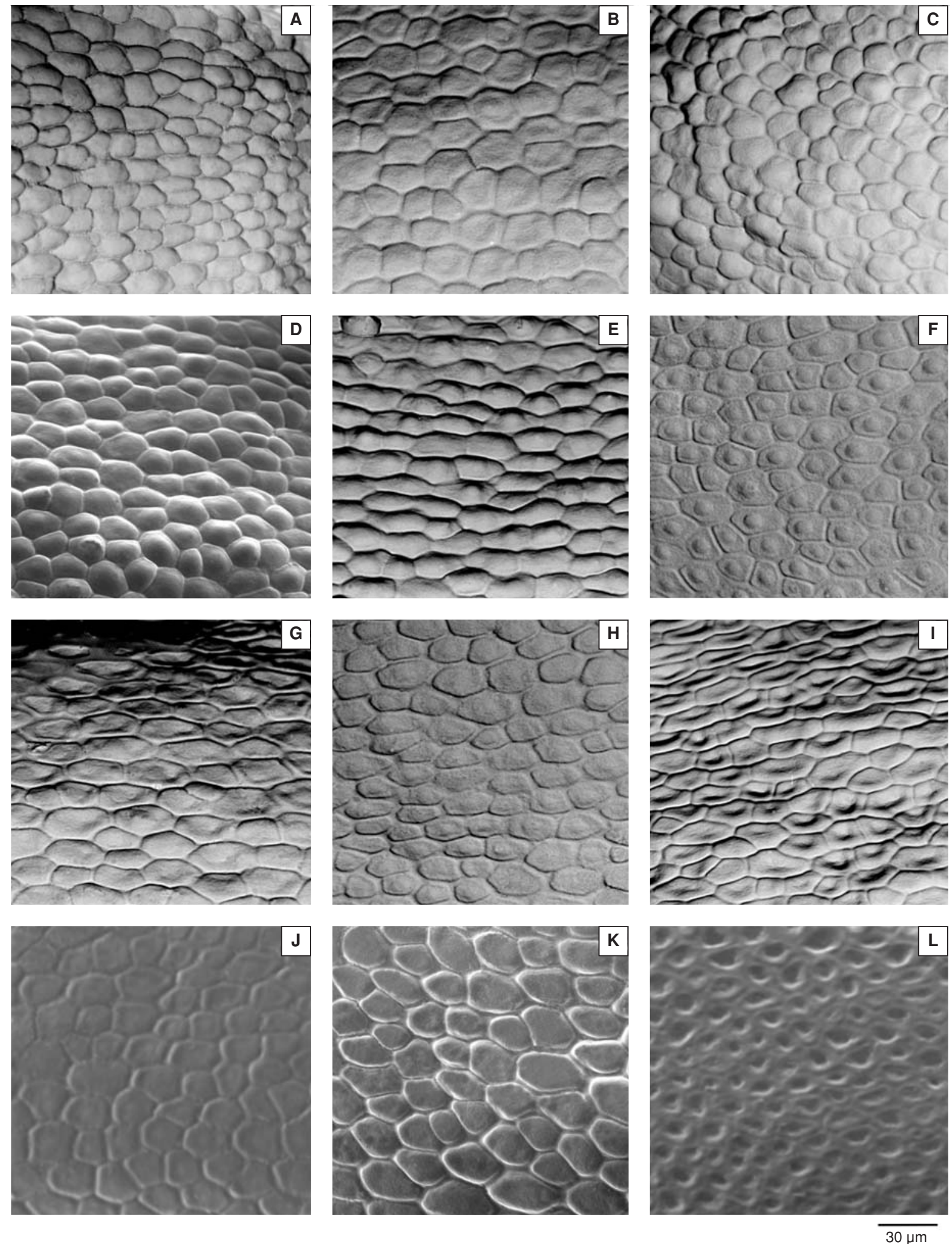

Fig. 1. Scanning electron micrographs of seed-coat surface of Trollius europaeus (A - Sitowiec; B - Ferdynandowo; C - Liszkowo; D - Popówek; E Łobżenica; F - Mnichy I; G - Uściskowo; H - Trzcielińskie Bagno I; I - Dziewicza Góra) and T. altissimus (J - Bobrowiec; K - Połonina Wetlińska; L Połonina Bukowska) populations.

with the margins clearly visible. The outer periclinal walls of testa cells were also variously formed: flat, concave, convex or with domed-like swell in the center (Fig. 1).

Analysis of variance showed that there exist significant differences in seed morphological traits among Trollius altissimus and T. europaeus $(\mathrm{p}<0.0001$; Table 2$)$. The seeds are small and are on average $1.6(1.4-1.9) \mathrm{mm}$ long and 1.1 (0.9-1.4) mm wide. However, the seeds of T. altissimus are a little bigger; on average $2.8 \%$ longer and $6.2 \%$ wider than the seeds of T. europaeus.

Analyzing the descriptive statistics at the population level of both species, we noticed that samples $1,8,10,13,15$ and 16 consisted of seeds of which the trait values significantly differed from the mean of parameters of all populations (Table 3). Furthermore, the values of all seed traits of populations $13,8,15,1,14$ and 17 (population sequence 
TABLE 3. Estimates of population effects on Trollius seed traits and values of test statistics: $T_{0, i, \bullet}^{2}$ and $T_{0}{ }^{2},{ }_{, j}$ (critical values at $\alpha=0.05$ are in brackets).

\begin{tabular}{|c|c|c|c|c|c|c|}
\hline \multirow{2}{*}{ No of population } & \multicolumn{5}{|c|}{ Trait } & \multirow{2}{*}{$T_{0}^{2}{ }^{2}{ }_{i \bullet}(11.1)$} \\
\hline & Length & Width & $\begin{array}{l}\text { Width/length } \\
\text { Ratio }\end{array}$ & Volume & $\begin{array}{l}\text { Projected } \\
\text { perimeter }\end{array}$ & \\
\hline 1 & $0.023 * *$ & $0.161 * *$ & 0.092 & $0.074 * *$ & $0.191 * *$ & 439.9 \\
\hline 2 & $-0.071 * *$ & $-0.069 * *$ & $-0.009 * *$ & $-0.054 * *$ & $-0.269 * *$ & 49.4 \\
\hline 3 & $-0.038 * *$ & $-0.072 * *$ & $-0.026 * *$ & $-0.046 * *$ & $-0.203 * *$ & 42.7 \\
\hline 4 & $-0.032 * *$ & $-0.112 * *$ & $-0.055^{* *}$ & $-0.073 * *$ & $-0.266^{* *}$ & 102.9 \\
\hline 5 & $-0.109 * *$ & $-0.110 * *$ & $-0.024 *$ & $-0.072 * *$ & $-0.398 * *$ & 87.5 \\
\hline 6 & $0.012 * *$ & $-0.119 * *$ & $-0.078 * *$ & $-0.063 * *$ & $-0.185 * *$ & 126.6 \\
\hline 7 & $-0.041 * *$ & $-0.084 * *$ & $-0.033 * *$ & $-0.055 * *$ & $-0.228 * *$ & 47.2 \\
\hline 8 & $0.092 * *$ & $0.172 * *$ & $0.065^{* *}$ & $0.095^{* *}$ & $0.362^{* *}$ & 924.0 \\
\hline 9 & $-0.063 * *$ & $-0.150 * *$ & $-0.067 * *$ & $-0.086 * *$ & $-0.382 * *$ & 163.3 \\
\hline 10 & $-0.179 * *$ & $-0.160 * *$ & $-0.026 * *$ & $-0.104 * *$ & $-0.545^{* *}$ & 340.2 \\
\hline 11 & $-0.114 * *$ & $-0.107 * *$ & $-0.018 *$ & $-0.074 * *$ & $-0.421 * *$ & 130.8 \\
\hline 12 & 0.003 & $-0.110 * *$ & $-0.065 * *$ & $-0.057 * *$ & $-0.164 * *$ & 97.2 \\
\hline 13 & $0.282 * *$ & $0.314 * *$ & $0.067 * *$ & $0.226^{* * *}$ & $0.914 * * *$ & 969.9 \\
\hline 14 & $0.086 * *$ & $0.195 * *$ & $0.082 * *$ & $0.106^{* * *}$ & $0.334 * *$ & 197.7 \\
\hline 15 & $0.208 * *$ & $0.263 * *$ & $0.072 * *$ & $0.179 * *$ & $0.704 * *$ & 752.5 \\
\hline 16 & $-0.119 * *$ & $-0.083 * *$ & 0.001 & $-0.040 * *$ & $0.476^{* *}$ & 2142.1 \\
\hline 17 & $0.058 * *$ & $0.072 * *$ & $0.022 * *$ & $0.046^{* *}$ & $0.083^{* *}$ & 159.0 \\
\hline$T_{0}^{2},_{\cdot j}(26.3)$ & 1862.8 & 3413.9 & 1131.2 & 3164.3 & 1551.8 & \\
\hline
\end{tabular}

* significant difference at level $\alpha=0.05$

** significant difference at level $\alpha=0.01$

with respect to seed size) were significantly larger than the means of all populations, while the seed traits of the remaining populations were significantly smaller than this mean. This indicated that the largest seeds were from $T$. altissimus populations (13, 15 and 14) and two populations of $T$. europaeus (8 and 1). The smallest seeds, however, were from $T$. europaeus populations 10 and 9. The seeds of $T$. altissimus population 16 were dissimilar to all other Trollius populations (without distinction of species; Fig. 1). It was a result of the small value of length and the large value of projected perimeter of seeds. All investigated populations of globeflower differed most by width and volume and the least by width/length ratio.

The dispersion of investigated populations of globeflower in the coordinate system given by the first two canonical variates adequately illustrate the results of multivariate analysis of variance. The first and second variates transfor- med 67.7 and $24.1 \%$ of the data, respectively (Fig. 2). This result is satisfactory with respect to use only the first two canonical variates. We analyzed the Mahalanobis distances to point out the pairs of Trollius populations, differing from each other. Four populations of T. altissimus (13, 15, 16, 17) significantly differed from all populations of T. europaeus. However, population 14 of T. altissimus did not significantly differ with $T$. europaeus population 8 . All investigated populations of $T$. altissimus were significantly different from each other. We observed significant differences between some pairs of T. europaeus populations (Table 4). Populations 1 and 8 varied from the other populations of $T$. europaeus, while populations 3 and 7 and 5 and 11 were similar (Fig. 2).

The contrast analysis between the means of $T$. altissimus and T. europaeus parameters, revealed significant differences between the seed traits of both species; the value of the

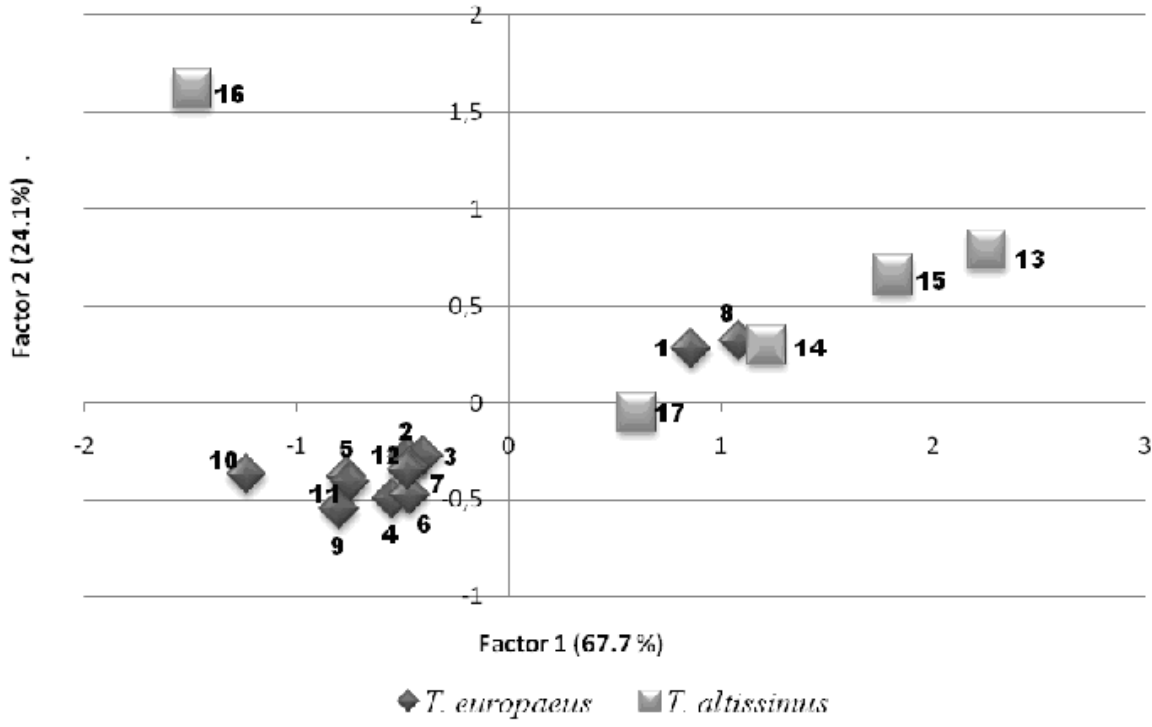

Fig. 2. The distribution of Trollius populations given by the first two canonical variables. 


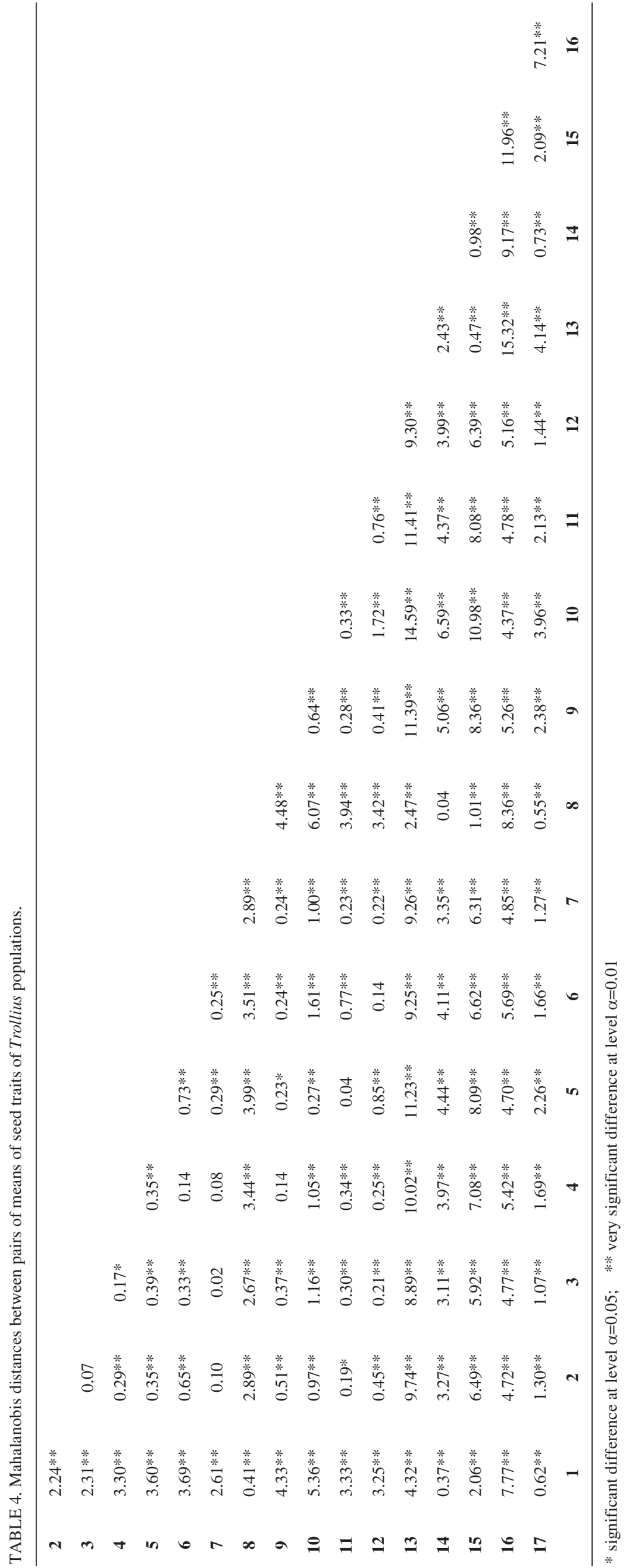

test statistics (1567.0) was greater than critical value (15.1; empirical level of significance is lower than 0.01).

\section{DISCUSSION AND CONCLUSION}

Seed sculpture did not differ between $T$. europaeus and $T$. altissimus. Statistical analysis showed that seeds of $T$. altissimus are larger than those of T. europaeus. However, both species appear to have similar seed morphological traits. There was a significant inter-population differentiation of seeds of both species with respect to seed-coat microsculpture and biometrical traits. In our previous study on chemical composition and morphology of basal leaves of these two species, we were also not able to separate T. altissimus from T. europaeus (Maciejewska-Rutkowska et al. 2007). Basing on our results, we conclude that $T$. europaeus and $T$. altissimus are not two distinct species.

The utility of seed morphological traits in distinguishing species for taxonomy has long been recognized (e.g. Martin 1946) and has been used to solve classification problems or to establish evolutionary relationships among related taxa (e.g. Zeng et al. 2004). The seed morphology, particularly seed-size, is not only of interest in taxonomy studies, but it is an important factor for understanding the mechanisms of species dynamics in plant communities (Janyszek et al. 2008). For instance, it is proven that large seeds are less important in open and disturbed environments than in closed and shady environments (Jakobsson and Eriksson 2000). Our investigation showed that $T$. europaeus and $T$. altissimus practically do not differ in seed morphology. We assume, however, that site conditions of globeflower populations may cause conspicuous variations of seed-coat sculpture as well as seed size or shape.

\section{ACKNOWLEDGEMENTS}

We thank dr. J. Ryan Stewart (University of Illinois at Urbana-Champaign, USA) for valuable comments on the early draft of the manuscript and linguistic support.

\section{LITERATURE CITED}

BARTHLOTT W. 1981. Epidermal and seed surface applicability and some evolutionary aspects. Nord. J. Bot. 1: 345-355.

BRÜCKNER C. 1994. Comparative seed structure in the Ranunculiflorae. Plant Syst. Evol., Suppl. 9: 83-84.

CAPPELLETTI E.M., POLDINI L. 1984. Seed morphology in some European aconites (Aconitum, Ranunculaceae). Plant Syst. Evol. 145(3-4): 193-201. 
CHRTEK J., CHRTKOVA A. 1979. Taxonomische Bemerkungen zur Art Trollius europaeus L. in der Tschechoslowakei. Preslia 51: 97-106.

CORNER E.J.H. 1976. The seeds of dicotyledons. Vol. 1. Cambridge University Press. Cambridge-London-New York-Melbourne.

DESPRÉS L., LORIOT S., GAUDEUL M. 2002. Geographic pattern of genetic variation in the European globeflower Trollius europaeus L. (Ranunculaceae) inferred from amplified fragment length polymorphism markers. Mol. Ecol. 11: 2337$-2347$.

DESPRÉS L., GIELLY L., REDOUTET B., TABERLET P. 2003. Using AFLP to resolve phylogenetic relationships in a morphologically diversified plant species complex when nuclear and chloroplast sequences fail to reveal variability. Mol. Phylogenet. Evol. 27: 185-196.

DESPRÉS L., Ibanez S., Hemborg L.M., Godelle B. 2007. Geographic and within-population variation in the globeflowerglobeflower fly interaction: the costs and benefits of rearing pollinators' larvae. Oecologia 151: 240-250

DOROSZEWSKA A. 1974. The genus Trollius L. A taxonomical study. Monogr. Bot. 41: 1-183.

ENDRESS P.K., IGERSHEIM A. 1999. Gynoecium diversity and systematics of the basal eudicots. Bot. J. Linn. Soc. 130: 305$-393$.

FENG-XIA X. 2003. Sclerotesta morphology and its systematic implications in magnoliaceous seeds. Bot. J. Linn. Soc. 142: 407-424.

HEPHER A., ROBERTS J.A. 1985a. The control of seed germination in Trollius ledebouri. The breaking of dormancy. Planta 166: 314-320.

HEPHER A., ROBERTS J.A. 1985b. The control of seed germination in Trollius ledebouri. A model of seed dormancy. Planta 166: 321-328.

HITCHMOUGH J.D. 2003. Effects of Sward height, gap size, and slug grazing on emergence and establishment of Trollius europaeus (Globeflower). Restorat. Ecol. 11(1): 20-28.

JANYSZEK M., JAGODZIŃSKI A.M., JANYSZEK S., WROŃSKA-PILAREK D. 2008. Morphological variability of Carex spicata Huds. utricles among plant communities. Flora 203: 386-395.
JAKOBSSON A., ERIKSSON O. 2000. A comparative study of seed number, seed size, seedling size and recruitment in grassland plants. Oikos 88: 494-502.

LEJEUNE M., CALIŃSKI T. 2000. Canonical analysis applied to multivariate analysis of variance. J. Multivar. Analysis 72: 100-119.

MACIEJEWSKA-RUTKOWSKA I., ANTKOWIAK W., JAGODZIŃSKI A.M., BYLKA, W., WITKOWSKA-BANASZCZAK E. 2007. Chemical composition and morphology of basal leaves of Trollius europaeus L. and T. altissimus Crantz (Ranunculaceae). Pol. J. Environ. Stud. 16(4): 605-615.

MARTIN A.C. 1946. The Comparative Internal Morphology of Seeds. Am. Midland Natural. 36(3): 513-660.

MIREK Z., PIĘKOŚ-MIRKOWA H., ZAJĄC A., ZAJĄC, M. 2002. Flowering plants and pteridophytes of Poland. A check list. W. Szafer Inst. Bot., Polish Acad. Scien., Kraków.

MORRISON D.F. 1976. Multivariate statistical methods. 2nd ed. McGraw-Hill, New York.

MOSYAKIN S.L., FEDORONCHUK M.M. 1999. Vascular plants of Ukraine. A nomenclatural checklist. National Acad. Scien. Ukraine, M.G. Kholodny Inst. Bot., Kiev.

PANKHURST R. 2006. PANDORA taxonomic data base system at the Royal Botanic Garden Edinburgh. rbg-web2.rbge.org. uk/FE/fe.html.

PIĘKOŚ-MIRKOWA H., MIREK Z. 2003. Flora Polski. Atlas roślin chronionych. Multico Oficyna Wydaw., Warszawa. (in Polish)

TUTIN T.G. 1993. Trollius L. In: Flora Europaea. Psilotaceae to Platanaceae. 1. 2ed. Tutin T.G., Burges N.A., Charter A.O., Edmondson J.R., Heywood V.H., Moore D.M., Valentine D.H., Walters S.M., Webb D.A. (eds). Cambridge University Press, pp. 253

YU D. W., RIDLEY J. 2003. Geopolitics in a buttercup. Trends Ecol. Evol. 18(4): 163-165.

ZENG CH.L., WANG J.B., LIU A.H., WU X.M. 2004. Seed coat microsculpturing changes during seed development in diploid and amphidiploid Brassica species. Ann. Bot. 93: 555-566.

ZICHA O. 2009. Taxon profile. Species Globe Flower Trollius altissimus Crantz. BioLib - Taxonomic tree of plants and animals with photos. www.biolib.cz/cz/taxon/id38303/. 